\title{
BREVES COMENTÁRIOS SOBRE A OBRA $O$ AFRICANO, DE JEAN-MARIE GUSTAVE LE CLEZIO
}

\author{
Antonio Carlos Lopes Petean (UFOP/UNESP) \\ acpetean@yahoo.com.br
}

O Africano, de Jean-Marie Gustave Le Clézio, é uma obra baseada nas memórias do autor. Memórias de sua infância na Nigéria, na região de Ogoja, sob domínio do império colonial inglês. Império que começou a ser consolidado em 1660 com a criação de entrepostos de captação de escravos para as colônias americanas.

Mas foi somente no século XVIII (1787) que a Inglaterra apossou-se de territórios entre o rio Gâmbia e a Nigéria, dando início ao projeto colonial britânico na África.

O colonialismo britânico no continente africano teve fim em 18 de abril de 1980 quando a Inglaterra e a Organização das Nações Unidas (ONU) reconheceram oficialmente a independência do Zimbabwe.

O livro, dividido em sete partes, é constituído das lembranças do escritor, quando foi viver com o pai na África, após a segunda guerra mundial. $\mathrm{O}$ pai do autor era médico-oficial do exército inglês e chegou à Nigéria em 1928. Esta obra pode servir aos professores, das mais diversas áreas, para trabalharem temas como História oral, educação ambiental e o imperialismo europeu no continente africano.

O autor chegou à África em 1948, com sua mãe e irmão. Eles foram viver com o pai, distantes da administração colonial inglesa. "O trabalho que meu pai fazia, primeiro em Camarões, depois na Nigéria, criava uma situação excepcional. A maioria dos ingleses lotados na colônia exercia funções administrativa" (LE CLÉZIO, 2007, p. 16) ${ }^{3}$.

\footnotetext{
${ }^{3}$ Daqui em diante, as referências à obra de Le Clézio serão feitas só com a indicação da página.
} 
Segundo Le Clézio, os militares, juízes e oficiais de distrito da administração colonial concentravam suas atividades próximas ao litoral e seu pai baseado num antigo hospital religioso no norte da província do Cross River, na região de Ogoja.

Portanto, segundo o escritor, "Nós, meu irmão e eu, éramos as únicas crianças brancas de toda aquela região. Não conhecemos nada do que foi capaz de forjar a identidade um pouco caricaturesca das crianças criadas nas colônias" (p. 17). E isto se deve ao isolamento a que estavam submetidos.

Ele descreve a humanidade com que convivera nesse período. Uma humanidade constituída, unicamente, de iorubás e ibos, grupos étnicos africanos que foram usados como mão de obra escrava nas colônias inglesas e portuguesas da América.

Os iorubás contribuíram de forma significativa para a construção do patrimônio cultural afro-brasileiro, principalmente, no campo religioso. O Candomblé tem sua origem ligada aos iorubás.

As memórias de Le Clézio dão o tom dessa obra. No início, descreve as primeiras sensações que teve ao entrar em contato com a África. Sensações que fizeram o autor esquecer dos duros anos em que viveu em Nice, na França, escondido num apartamento durante a segunda guerra mundial, cujas únicas recordações são o barulho das bombas caindo sobre a cidade, o tráfico, a falta de alimentos e medicamentos e as mentiras.

O autor é enfático ao tratar da França ocupada, destacando as atrocidades cometidas pela aviação alemã. Estas são suas lembranças da Europa, que contrastam com suas lembranças da África.

$\mathrm{Na}$ África, o autor relata que suas sensações se multiplicaram, sensações de liberdade. Essa multiplicação, nas palavras dele, seria motivada pela nova humanidade que estava diante dele e da qual fez parte.

Uma humanidade visível nos corpos africanos à sua volta. Tudo muito estranho para um garoto europeu. "Na África, a falta de pudor dos corpos era magnífica. Dava profundidade, dava alcance, multiplicava as sensações, estendia a minha volta uma rede humana" (p. 9).

Desse tempo, por assim dizer consecutivamente, data o aparecimento dos corpos. Meu corpo, o corpo de minha mãe, o corpo de meu irmão, o corpo dos garotos da vizinhança com os quais eu brincava, o corpo das mulheres africanas nos caminhos, ao redor da casa, ou então no mercado, perto do rio. Sua es- 


\section{FACULDADE DE FORMAÇÃO DE PROFESSORES}

tatura, seus seios pesados, a pele luzente de suas costas. O sexo dos garotos, sua glande circuncisa (p. 8).

Os corpos, segundo os relatos, são a alteridade que lhe causa a primeira sensação de liberdade e estranhamento na infância em Ogoja. Com maestria o autor aborda a questão da alteridade representada pelos corpos europeus e africanos.

No decorrer da obra, Le Clézio deixa transparecer, que as sensações que sentia eram, também, confrontadas com as crenças africanas. Relata que uma de suas principais brincadeiras era destruir cupinzeiros, comparados pelo autor a torres de castelo.

Devemos ter começado jogando pedras, para sondar, para escutar o barulho que elas faziam ao bater nos cupinzeiros. A pauladas, atacávamos depois as torres altas, para ver a terra esfarinhada ruir, para expor à luz as galerias e os bichos cegos que viviam lá dentro (p. 25).

Nas palavras de Le Clézio, através desse ato, "pode ser que desse modo rejeitássemos a autoridade excessiva de nosso pai, revidando golpe com golpe através de nossas pauladas" (p. 26).

O escritor conta que os garotos africanos da aldeia nunca os acompanhavam nessa raiva demolidora. Podemos perceber também a alteridade em relação ao respeito com a natureza.

Já que o mundo no qual eles viviam os cupins eram algo que se impunha, tendo um papel a representar nas lendas. No começo do mundo, o deus-cupim tinha criado os rios, e era ele o guardião das águas para os habitantes da terra. Por que então destruir sua morada? (p. 26).

Nessa passagem, evidencia, o autor, a relação entre as crenças africanas e a natureza, algo que lhe era estranho enquanto um europeu. Crenças africanas transmitidas por meio da cultura oral, evidenciando o caráter pedagógico da oralidade africana. $\mathrm{O}$ resultado, se é que se pode utilizar este termo, seria o respeito pela natureza por parte das crianças africanas.

Mas o autor apresenta ao leitor a ação do imperialismo inglês em sua ânsia por matéria-prima, ao recordar que "no meio da savana, erguiam-se grandes árvores de tronco muito reto, as quais serviam, conforme vim saber mais tarde, para fornecer os assoalhos de mogno dos países industrializados" (p. 24).

O memorialista demonstra, ainda, sua indignação para com a administração colonial inglesa. Por certo, uma indignação herdada das imagens que seu pai presenciou e lhe transmitiu na infância, pois declara Le 
Clézio que a África começou para meu pai quando ele tocou na costa do ouro, em Acra. Imagens características da colônia: viajantes europeus, vestidos de branco e com capacetes cawnpore na cabeça, são desembarcados num bote e transportados para a terra a bordo de uma piroga tripulada por negros. Essa era a África que mais expatriava: resume-se ela à estreita faixa que acompanha o litoral, desde a ponta do Senegal até o Golfo da Guiné, conhecida por todos que vêm das metrópoles para fazer negócios e enriquecer rapidamente.

Região que forneceu para a América boa parte dos negros escravizados. Escravizados que vieram trabalhar nas plantações de cana-deaçúcar, algodão e café. Na África colonial não foi diferente o destino de milhares de africanos.

Uma sociedade que em menos de meio século "se arquitetou em castas, lugares reservados, proibições, privilégios, abusos e lucros" (p. 62). E diz ainda, sobre esse mundo colonial africano, que, as esposas dos oficiais e dos administradores ingleses, projetavam nos serviçais africanos todo o rancor que possuíam.

Le Clézio se recorda que o território a cargo de seu pai era imenso, "Vai da fronteira com o protetorado francês de Camarões, ao sudeste, até os confins de Adamawa, ao norte e abrange a maior parte das chefias e dos pequenos reinos que escapam à autoridade direta da Inglaterra" (p. 75).

Diz ainda, que "Não são, porém, regiões isoladas nem selvagens" (p. 77). Lembra o autor que, eram regiões prósperas, com grandes áreas cultivadas e de pecuária. “...não é a África de Tartaris de Tarascon, nem sequer a de John Huston. É, antes, a de Out of Africa, uma África real, de grande densidade humana" (p. 81). Uma África com grande densidade populacional e uma vasta cultura.

Ele se recorda que seu pai tomou consciência de sua profissão e papel, ao perceber que o médico é um agente administrativo tal qual o policial ou o juiz.

A prática da medicina também é um poder sobre pessoas, sendo a vigilância médica, igualmente uma vigilância política. Bem o sabia o exército britânico, ele que, no começo do século, após anos de resistência encarniçada, pôde vencer pela força das armas e da técnica moderna a magia dos últimos guerreiros ibos (p. 97). 


\section{FACULDADE DE FormaÇÃo de PROFESSORES}

Fica evidente que a medicina é uma prática usada pelo sistema colonial para dominar e controlar populações no continente africano. A medicina usada como uma nova forma de poder no mundo contemporâneo.

Todas essas memórias, apresentadas nesta obra, são também as memórias de seu pai e, também, são suas angústias. Como o próprio Le Clézio admite, "Essa memória não é somente a minha. É também a memória do tempo anterior ao meu nascimento..." (p. 122). "A memória das esperanças e angústias de meu pai, de sua solidão, seu abatimento em Ogoja" (p. 122). Abatimento devido a destruição provocada pelo colonialismo inglês no continente africano.

Le Clézio observa em seu pai a angustia de quem vê a administração colonial inglesa como destrutiva e arrogante. Como algo que caminha para uma catástrofe. Neste sentido a obra permite uma crítica ao colonialismo europeu.

De volta à Europa, já nos anos 60, o autor partilha das angustias de seu pai com as notícias que chegam da África, principalmente com as noticias sobre a guerra em Biafra, que opõe ibos e iorubás e a guerra da independência da Argélia. Por fim, relata Le Clézio: "Vi imagens terríveis em todos os jornais e revistas. Pela primeira vez, o país onde eu havia passado a parte mais memorável de minha infância era mostrado ao resto do mundo, mas apenas por estar à morte." (p. 117).

Estas são as memórias e impressões resgatadas pelo autor durante alguns anos passados da infância na Nigéria e que agora contrastam com as notícias sobre as guerras que destroçam o continente africano. Guerras que são resultado de anos de colonialismo europeu no continente.

A contribuição desta obra só poderá ser alcançada se percebermos a importância da história oral, da religiosidade africana e dos contos africanos para uma prática pedagógica que possa pensar a educação ambiental e o respeito à diversidade cultural.

Com certeza esta obra colabora para a aplicação da lei 10.639/03 que introduz o ensino de história da África e da cultura afro-brasileira e africana no sistema educacional brasileiro. Lei que tem como meta combater o racismo e todas as formas de preconceito em relação a cultura de matriz africana presente em solo nacional. 


\section{REFERÊNCIAS BIBLIOGRÁFICAS}

FOUCAULT, Michel. Vigiar e punir. São Paulo: Vozes, 2007.

HUGON, Philippe. Geopolítica da África. Rio de Janeiro: Fundação Getúlio Vargas, 2009.

JÚNIOR, Caio Prado. Formação do Brasil contemporâneo. São Paulo: Brasiliense, [s/d?].

LE CLÉZIO, Jean-Marie Gustave. O africano. São Paulo: Cosac Naify, 2007. 